\title{
PARTISIPASI MASYARAKAT DALAM PEMBANGUNAN JEMBATAN PERKEBUNAN DI DESA KANEYAN KECAMATAN TARERAN KABUPATEN MINAHASA SELATAN
}

\author{
Shania Fonika Intan Umboh \\ Elsje Pauline Manginsela \\ Vicky Richard Bernhard Moniaga
}

Naskah diterima melalui Email agrisosioekonomi@unsrat.ac.id

: Senin, 20 Juli 2020

Disetujui diterbitkan

Rabu, 22 Juli 2020

\begin{abstract}
This study aims to describe how the level and form of community participation in the construction of plantation bridges in Kaneyan Village, Tareran District, South Minahasa Regency. The study was conducted in November 2019 until April 2020. The data used in this study are primary and secondary data. Primary data were obtained through direct interviews with 30 respondents using a questionnaire and secondary data obtained from the Kaneyan village government office. The sampling technique was done intentionally (purposive sampling). Analysis of the data used in the research is a descriptive analysis method by making tables and percentages to explain the level and form of community participation in the construction of plantation bridges. Measurement of the level of participation using a Likert Scale. The results showed that the level of participation of the Kaneyan Village community in the plantation bridge construction program at the planning, implementation and maintenance stages and in the form of mind, energy, skills and goods participation was at a percentage of $57.51 \%$ included in the Participating category. ${ }^{*}$ eprm*
\end{abstract}

Keywords: participation, level, form, community, Likert Scale

\begin{abstract}
ABSTRAK
Penelitian ini bertujuan untuk mendeskripsikan bagaimana tingkat dan bentuk partisipasi masyarakat dalam pembangunan jembatan perkebunan di Desa Kaneyan Kecamatan Tareran Kabupaten Minahasa Selatan. Penelitian dilaksanakan pada bulan November 2019 sampai bulan April 2020. Data yang digunakan dalam penelitian ini adalah data primer dan sekunder. Data primer diperoleh melalui wawancara langsung kepada 30 responden dengan menggunakan kuesioner dan data sekunder data yang diperoleh dari kantor pemerintah Desa Kaneyan. Teknik pengambilan sampel dilakukan secara sengaja (purposive sampling). Analisis data yang digunakan dalam penelitian adalah metode analisis deskriptif dengan membuat tabel dan persentase untuk menjelaskan tingkat dan bentuk partisipasi masyarakat dalam pembangunan jembatan perkebunan. Pengukuran tingkat partisipasi menggunakan Skala Likert. Hasil penelitian menunjukkan bahwa tingkat partisipasi masyarakat Desa Kaneyan dalam program pembangunan jembatan perkebunan pada tahap perencanaan, pelaksanaan, dan pemeliharaan dan dalam bentuk partisipasi pikiran, tenaga, keterampilan dan barang berada pada persentase 57,51\% termasuk pada kategori Berpartisipasi. *eprm*
\end{abstract}

Kata kunci: partisipasi, tingkat, bentuk, masyarakat, Skala Likert

Agrisosioekonomi: 


\section{PENDAHULUAN}

\section{Latar Belakang}

Pembangunan desa dapat diartikan sebagai pembangunan dari rakyat, oleh rakyat dan untuk rakyat dimana merupakan proses peningkatan kemampuan penduduk desa untuk memahami dan menguasai lingkungan sosial yang disertai dengan meningkatnya taraf hidup masyarakat. Salah satu hal penting dalam menujang pembangunan desa adalah pembangunan infrastruktur. Hal ini di tegaskan oleh Adisasmita (2006) bahwa prasarana fisik mempunyai peran yang sangat penting untuk menunjang berbagai kegiatan ekonomi dan sosial dalam meningkatkan pertumbuhan ekonomi, pemerataan dan kesejahteraan rakyat.

Pembangunan terdiri dari pembangunan fisik dan non-fisik. Pembangunan fisik adalah pembangunan yang dapat dirasakan langsung oleh masyarakat atau pembangunan yang tampak oleh mata (Kuncoro, 2010). Pembangunan fisik antara lain berupa infrastruktur, bangunan dan fasilitas umum, sedangkan pembangunan non-fisik adalah jenis pembangunan yang tercipta oleh dorongan masyarakat setempat dan memiliki jangka waktu yang lama. Contoh dari pembangunan non-fisik antara lain berupa peningkatan perekonomian masyarakat desa, dan peningkatan kesehatan masyarakat (Wresniwiro, 2012).

Menurut Rorong (2017) partisipasi masyarakat merupakan suatu proses teknis untuk memberikan kesempatan dan kewenangan yang lebih luas kepada masyarakat secara bersamasama untuk memecahkan berbagai persoalan. Partisipasi masyarakat juga sering diperbincangkan diberbagai wilayah, baik di daerah kota maupun pedesaan, karena dapat kita lihat begitu besar pengaruh dari partisipasi tersebut. Partisipasi masyarakat ini sangat menentukan keberhasilan suatu perencanaan atau program-program yang ada. Keberhasilan suatu program tanpa adanya partisipasi masyarakat tidak akan berjalan dengan baik. Keikutsertaan masyarakat akan sangat dibutuhkan dalam perencanaan atau program, agar program berjalan dengan baik. Agar pembangunan berjalan sebagaimana yang diharapkan, maka diperlukan partisipasi dari masyarakat dalam menjalankan aktivitas pembangunan tersebut.
Menurut Ericson dalam Slamet (1993) bentuk partisipasi yang di berikan kepada masyarakat dalam pembangunan terbagi menjadi tiga tahapan, yaitu: pertama partisipasi dalam tahap perencanaan, kedua partisipasi dalam tahap pelaksanaan, dan ketiga partisipasi dalam tahap pemeliharaan. Adapun jenis partisipasi masyarakat antara lain: partisipasi pikiran, partisipasi tenaga, partisipasi keterampilan, partisipasi barang (perlengkapan), dan partisipasi uang (dana) (Hamijoyo, 2007).

Desa Kaneyan adalah desa yang mayoritas penduduknya adalah pekebun yang menguasai lahan pertanian pada lahan perkebunan yang relatif luas. Letak perkebunan-perkebunan tersebut berada jauh dari desa dengan medan yang cukup sulit untuk dilalui petani di Desa Kaneyan. Hal ini mempengaruhi proses berkebun para petani di antaranya waktu tempuh yang panjang, dan proses pengangkutan hasil pertanian yang terbatas. Perjalanan ke perkebunan dilalui dengan berjalan kaki karena harus melewati sungai yang airnya sangat deras dan dipenuhi dengan batuan yang besar sehingga tidak dapat menggunakan transportasi kendaraan roda dua maupun roda empat. Oleh karena itu pada saat ini Desa Kaneyan melalui pemerintah desa telah melaksanakan program pembangunan desa yang dananya berasal dari dana desa yaitu pembuatan jembatan perkebunan. Jembatan ini merupakan akses penghubung dari rumah penduduk di desa ke lokasi perkebunan mereka. Pembangunan jembatan ini dilakukan untuk memudahkan dan mempersingkat anggota masyarakat Desa Kaneyan melakukan perjalanan ke perkebunan dengan menggunakan alat transportasi seperti motor atau mobil, dan dapat mengangkut hasil panen yang lebih banyak. Jembatan ini dibangun dalam waktu 3 bulan yaitu dari bulan Mei 2019 hingga bulan Agustus 2019.

Berdasarkan uraian diatas maka penelitian ini dilakukan untuk mengetahui partisipasi masyarakat dalam pembangunan jembatan perkebunan di Desa Kaneyan Kecamatan Tareran Kabupaten Minahasa Selatan, serta untuk mengetahui bagaimana tingkat dan bentuk partisipasi masyarakat pada tahap perencanaan, tahap pelaksanaan, sampai tahap pemeliharaan. 


\section{Partisipasi Masyarakat}

Pengertian partisipasi dikemukakan oleh berbagai ilmuwan. Wasir (1999) mengemukakan bahwa partisipasi dapat diartikan sebagai keterlibatan seseorang secara sadar ke dalam interaksi sosial dalam situasi tertentu. Sedangkan menurut Isbandi (2007) partisipasi adalah keikutsertaan masyarakat dalam proses pengidentifikasian masalah dan potensi yang ada di masyarakat, pemilihan dan pengambilan keputusan tentang alternatif solusi untuk menangani masalah, pelaksanaan upaya mengatasi masalah, dan keterlibatan masyarakat dalam proses mengevaluasi perubahan yang terjadi.

Menurut Juliantara (2004), partisipasi juga dapat diartikan sebagai keterlibatan masyarakat dalam pembangunan diri, kehidupan, dan lingkungan mereka. Partisipasi pada hakekatnya juga menyangkut keterlibatan mental dan emosional atau perilaku seseorang sebagai masyarakat, serta fisik seseorang dalam memberikan tanggapan terhadap kegiatan yang di laksanakan dalam proses belajar mengajar serta mendukung pencapaian tujuan dan bertanggung jawab atas keterlibatannya.

Mikkelsen (2011) mengemukakan bahwa partisipasi adalah kontribusi sukarela dari masyarakat kepada proyek tanpa ikut serta dalam pengambilan keputusan serta suatu proses yang aktif yang mengandung arti bahwa orang atau kelompok yang terkait, mengambil inisiatif dan menggunakan kebebasannya untuk melakukan hal itu.

Berdasarkan definisi dari beberapa para ahli, partisipasi yaitu keterlibatan aktif dari seseorang atau kelompok orang (masyarakat) secara sadar untuk berkontribusi secara sukarela dalam program pembangunan dan terlibat mulai dari perencanaan, pelaksanaan, sampai pada tahap pemeliharaan.

Menurut Isbandi (2007) partisipasi masyarakat adalah keikutsertaan masyarakat dalam proses mengidentifikasi masalah dan potensi yang ada di masyarakat, pemilihan dan pengambilan keputusan tentang alternatif solusi untuk menangani masalah, pelaksanaan upaya mengatasi masalah, dan keterlibatan masyarakat dalam proses mengevaluasi perubahan yang terjadi. Sedangkan Adisasmita (2006) menyatakan, partisipasi masyarakat adalah pemberdayaan masyarakat, peran sertanya dalam kegiatan penyusunan perencanaan dan implementasi program atau proyek pembangunan, dan merupakan aktualisasi dan kesediaan dan kemauan masyarakat untuk berkorban dan berkontribusi terhadap implementasi program pembangunan.

\section{Pentingnya partisipasi masyarakat}

Menurut Supriatna (2000) ada tiga alasan utama mengapa partisipasi masyarakat menjadi sangat penting, yaitu:

1. Partisipasi masyarakat merupakan suatu alat ukur untuk memperoleh informasi mengenai kondisi, dan kebutuhan masyarakat setempat, yang tanpa kehadirannya program pembangunan serta proyek-proyek akan gagal.

2. Bahwa masyarakat akan lebih mencapai proyek atau program pembangunan jika merasa dilibatkan dalam proses persiapan dan perencanaannya, karena mereka akan lebih mengetahui perihal proyek tersebut.

3. Adanya anggapan bahwa merupakan suatu hak demokrasi bila masyarakat dilibatkan dalam pembangunan masyarakat itu sendiri.

\section{Bentuk Partisipasi Masyarakat}

Bentuk partisipasi masyarakat menurut Hamijoyo (2007) yaitu:

1. Partisipasi pemikiran, adalah partisipasi berupa sumbangan ide, pendapat atau buah pikiran konstruktif, baik untuk menyusun program maupun untuk memperlancar pelaksanaan program dan juga untuk mewujudkan dengan memberikan pengalaman dan pengetahuan guna mengembangkan kegiatan yang di ikutinya.

2. Partisipasi tenaga, adalah partisipasi yang diberikan dalam bentuk tenaga untuk pelaksanaan usaha-usaha yang dapat menunjang keberhasilan suatu program.

3. Partisipasi keterampilan, adalah memberikan dorongan melalui keterampilan yang dimilikinya kepada anggota masyarakat lain yang membutuhkannya. Dengan maksud agar orang tersebut dapat melakukan kegiatan yang dapat meningkatkan kesejahteraan sosialnya.

4. Partisipasi barang, merupakan jenis partisipasi masyarakat yang diberikan dalam bentuk barang yang mencakup peralatan dan perlengkapan yang di butuhkan. Barang yang di maksudkan dalam 
hal ini adalah barang-barang yang dimiliki oleh anggota yang secara sukarela digunakan untuk keperluan kegiatan atau acara dari kampung kreatif.

5. Partisipasi uang, adalah bentuk partisipasi untuk memperlancar usaha-usaha bagi pencapaian kebutuhan masyarakat yang memerlukan bantuan. Partisipasi ini menggunakan uang sebagai alat guna mencapai sesuatu yang diinginkan biasanya tingkat partisipasi tersebut dilakukan oleh orang-orang pada kalangan atas.

\section{Tahapan Partisipasi Masyarakat}

Menurut Ericson dalam Slamet (1993)

bentuk partisipasi masyarakat dalam pembangunan terbagi atas 3 tahap yaitu:

1. Partisipasi dalam tahap perencanaan yaitu partisipasi keterlibatan seseorang pada tahap penyusunan rencana dan strategi dalam penyusunan rencana program pembangunan dan anggaran pada suatu kegiatan atau proyek. Masyarakat mampu berpartisipasi dengan memberikan usulan, saran, kritik, melalui pertemuan yang di adakan.

2. Partisipasi dalam tahap pelaksanaan yaitu keterlibatan seseorang pada suatu pekerjaan atau proyek. Masyarakat memberikan tenaga, uang, ataupun material atau barang, serta ideide sebagai salah satu wujud partisipasinya pada pekerjaan tersebut.

3. Partisipasi pada tahap pemeliharaan yaitu keterlibatan seseorang pada tahap pemeliharan suatu proyek setelah proyek tersebut selesai dikerjakan. Partispasi masyarakat pada tahap ini berupa tenaga, uang pengoprasian, serta memelihara proyek yang telah di bangun.

\section{Pembangunan infrastruktur dan Desa}

Menurut Mustanir dan Darmiah (2016), pembangunan diartikan sebagai suatu proses yang menggambarkan adanya pengembangan baik meliputi proses pertumbuhan ataupun perubahan dalam kehidupan bersama atau organisasi, sosial dan budaya. Sedangkan Effendi (2014) pembangunan adalah suatu upaya untuk meningkatkan segenap sumber daya yang dilakukan secara berencana dan berkelanjutan dengan prinsip daya guna dan hasil guna yang merata dan berhasil. Pembangunan memiliki arti, yaitu suatu proses yang menggambarkan adanya pengembangan, baik meliputi proses pertumbuhan, ataupun perubahan dalam kehidupan bersama (organisasi) sosial dan budaya.

Menurut Mustanir dan Jusman (2016), pembangunan itu baik dari segi perencanaan maupun dalam pelaksanaanya, harus membuahkan hasil dari masyarakat luas. Artinya bahwa bentuk serta cara hidup yang lebih baik dan lebih sejahtera dari keadaan sebelumnya, termasuk pengembangan potensi dan sumber kehidupan dimasa yang akan datang, bahwa sifat dan watak pembangunan yang akan dicapai itu harus sedemikian rupa bercirikan multidimensional, artinya bahwa pembangunan itu tidak harus saja mencakup suatu aspek saja melainkan harus mencakup seluruh aspek kehidupan

\section{Pembangunan Infrastruktur}

Pembangunan fisik atau infrastruktur menurut Effendi (2014), pentingnya infrastruktur sebagai penunjang pelaksanaan pembangunan yang memadai yang berupa ketersediaan fasilitas pelayanan publik baik prasarana jalan, air bersih, listrik, jembatan, sarana pendidikan, sarana kesehatan, rumah ibadah, transportasi, irigasi, teknologi dan komunikasi bertujuan agar masyarakat dapat bergerak lebih dinamis dan mempermudah kegiatan ekonomi. Infrastruktur merujuk pada sistem fisik yang menyediakan transportasi, pengairan, drainase, bangunanbangunan gedung dan fasilitas publik yang lain yang dibutuhkan untuk memenuhi kebutuhan dasar manusia dalam lingkup sosial dan ekonomi. Infrastruktur adalah berbagai fasilitas fisik yang dibutuhkan dan dikembangkan oleh agen-agen publik yang bertujuan untuk memenuhi tujuan sosial dan ekonomi.

\section{Pembangunan Desa}

Pembangunan desa atau kelurahan mempunyai makna membangun masyarakat pedesaan dengan mengutamakan pada aspek kebutuhan masyarakat. Adisasmita (2006) mengemukakan bahwa pembangunan desa merupakan seluruh kegiatan pembangunan yang berlangsung di desa dan meliputi seluruh aspek kehidupan masyarakat, serta dilaksanakan secara 
terpadu dengan mengembangkan swadaya gotong royong, tujuannya adalah untuk meningkatkan kesejahteraan masyarakat desa berdasarkan kemampuan dan potensi sumber daya (SDA) mereka melalui peningkatan kualitas hidup, keterampilan dan prakarsa masyarakat.

\section{Rumusan Masalah}

Perumusan masalah pada penelitian adalah bagaimana tingkat dan bentuk partisipasi masyarakat pada tahap perencanaan, tahap pelaksanaan dan tahap pemeliharaan dalam pembangunan jembatan perkebunan di Desa Kaneyan Kecamatan Tareran Kabupaten Minahasa Selatan?

\section{Tujuan Penelitian}

Tujuan dari penelitian adalah untuk mendeskripsikan bagaimana tingkat dan bentuk partisipasi masyarakat dalam pembangunan jembatan perkebunan di Desa Kaneyan Kecamatan Tareran Kabupaten Minahasa Selatan.

\section{Manfaat Penelitian}

Manfaat dari penelitian ini yaitu:

1. Manfaat dalam penelitian ini bagi penulis adalah untuk meningkatkan pengetahuan tentang partisipasi masyarakat dalam pembangunan infrastruktur di Desa Kaneyan Kecamatan Tareran Kabupaten Minahasa Selatan.

2. Manfaat untuk masyarakat meningkatkan pengetahuan perlunya partisipasi masyarakat dalam mengikuti serta menjalankan program pembangunan khususnya pembangunan jembatan pembangunan.

3. Manfaat bagi pemerintah adanya data tingkatan partisipasi masyarakat dalam pembangunan jembatan perkebunan di Desa Kaneyan Kecamatan Tareran Kabupaten Minahasa Selatan.

\section{METODE PENELITIAN}

\section{Tempat dan Waktu Penelitian}

Tempat penelitian yang dipilih yaitu di Desa Kaneyan Kecamatan Tareran Kabupaten Minahasa Selatan. Waktu penelitian dilaksanakan pada bulan November 2019 sampai April 2020.

\section{Metode Pengumpulan Data}

Data yang digunakan dalam penelitian ini adalah data primer dan data sekunder. Data primer adalah data yang diperoleh secara langsung melalui wawancara, dimana wawancara merupakan suatu proses penggalian data yang di lakukan oleh peneliti untuk mendapatkan informasi sesuai fakta yang ada melalui daftar pertanyaan kepada responden. Sedangkan, data sekunder adalah data yang diperoleh dari kantor pemerintah Desa Kaneyan.

\section{Metode Pengambilan Sampel}

Metode pengambilan sampel dilakukan secara sengaja (purposive sampling) yaitu teknik pengambilan sampel yang digunakan dalam keadaan dimana peneliti memilih responden sebagai sasaran penilaian. Penentuan sampel 18 responden adalah dari pemerintah Desa Kaneyan sedangkan 12 responden adalah keterwakilan dari Jaga 1 sampai Jaga 5 sehingga jumlah sampel diperoleh sebanyak 30 orang.

\section{Konsep Pengukuran Variabel}

Variabel dalam penelitian ini mencakup tingkat partisipasi masyarakat yaitu karakteristik responden, dan bentuk partisipasi responden pada 3 tahap pembangunan jembatan yaitu tahap perencanaan, tahap pelaksanaan, dan tahap pemeliharaan.

\section{Metode Analisis Data}

Analisis data yang digunakan dalam penelitian adalah metode analisis deskriptif kualitatif dengan membuat tabel dan persentase untuk menjelaskan tingkat partisipasi masyarakat dalam pembangunan jembatan perkebunan. Pengukuran tingkat dan bentuk partisipasi menggunakan Skala Likert. Menurut Sugiono (2009), skala likert digunakan untuk mengukur sikap, pendapat dan persepsi seseorang atau sekelompok orang tentang fenomena sosial. Kategori pengukuran partisipasi yaitu:

1. Sangat Berpartisipasi nilai skor $=5$

2. Berpartisipasi nilai skor $=3$

3. Kurang berpartisipasi

Cara perhitungan skor keseluruhan: Jumlah skor seluruh kriteria = Capaian jumlah skor $\mathrm{x}$ jumlah responden $\mathrm{x}$ jumlah Instrumen pertanyaan. 
$\mathrm{SB}=5 \times 30 \times 15=2,250$

$\mathrm{B} \quad=3 \times 30 \times 15=1,350$

$\mathrm{KB}=1 \times 30 \times 15=450$

Jumlah skor ideal untuk keseluruhan pernyataan 2,250 ini merupakan yang tertinggi, sedangkan jumlah skor terendah 450. Dengan interpretasi nilai:

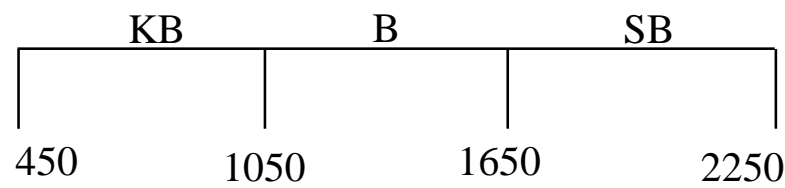

Menurut Riduan (2010) metode analisis deskriptif dengan menggunakan skala pengukuran tingkat partisipasi adalah sebagai berikut :

$$
\text { Tingkat Partisipasi }=\frac{\text { Jumlah skor hasil pengukuran }}{\text { Jumlah skor ideal tertinggi }} \times 100 \%
$$

Dengan interpretasi nilai persentase :

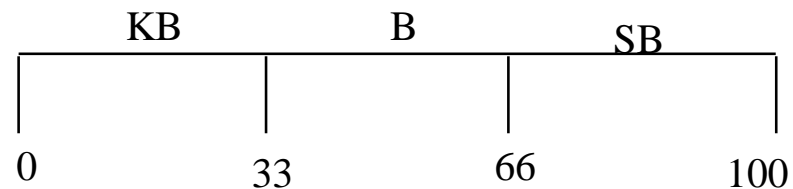

Angka $=0-33 \%$ Kurang Berpartisipasi

Angka $=34-66 \%$ Berpartisipasi

Angka $=67-100 \%$ Sangat Berpartisipasi

\section{HASIL DAN PEMBAHASAN}

\section{Deskripsi Umum Lokasi Penelitian}

Desa Kaneyan adalah salah satu desa yang terletak di Kecamatan Tareran Kabupaten Minahasa Selatan. Kata Kaneyan berasal dari bahasa Tountemboan Minahasa yaitu Pataneyan yang berarti teringat selalu. Desa Kaneyan mempunyai luas wilayah $733 \mathrm{Ha}$, terdiri dari lima jaga dengan jumlah penduduk sebanyak 982 jiwa, dengan 470 KK. Potensi Desa Kaneyan antara lain, pertanian perkebunan dan peternakan. Pertanian terdiri dari Holtikultura yang luasnya $185 \mathrm{Ha}$, Kelapa 176 Ha, Cengkih 100 Ha, Vanili 15 Ha, dan Padi 64 Ha. Peternakan terdiri dari Ayam, Bebek, Sapi dan Babi, Sarana dan prasarana umum di desa ini yaitu bangunan sekolah terdapat: Taman kanakkanak (TK) 1 unit, Sekolah Dasar (SD) 1 unit, Sekolah Menengah Pertama (SMP) 1 unit. Bangunan tempat ibadah GMIM 1 unit, dan GPdI 1 unit. Adapun batas-batas wilayah Desa Kaneyan, yaitu:
Sebelah Utara : Wilayah Kepolisian Desa Pinamorongan Kecamatan Tareran.

Sebelah Timur : Wilayah Kepolisian Desa Koreng Kecamatan Tareran dan Wilayah Kepolisian Desa Wuwuk Barat Kecamatan Tareran.

Sebelah Selatan : Wilayah Kepolisian Desa Maliku Kecamatan Amurang Timur.

Sebelah Barat : Wilayah Kepolisian Desa Ritey Kecamatan Tareran.

Pemerintah Desa Kaneyan dalam mendukung potensi desa yang ada melakukan program pembangunan-pembangunan, seperti pembangunan jembatan menuju ke perkebunan. Jembatan ini dibuat berdasarkan hasil keputusan rapat musyawarah desa yang dananya berasal dari dana desa. Pembangunan ini dilakukan untuk memudahkan masyarakat Desa Kaneyan dalam melakukan perjalanan keperkebunan sehingga dapat menggunakan alat transportasi. Sebelumnya untuk dapat melakukan perjalanan menuju ke perkebunan yang dilalui dengan berjalan kaki karena harus melewati sungai yang airnya sangat deras dan dipenuhi dengan bebatuan yang besar. Sebelum pelaksanaan pembuatan jembatan perkebunan dilakukan pemerintah dan sebagian masyarakat Desa Kaneyan melakukan kerja bakti dalam rangka pembersihan area sungai sebelum dilakukan pembuatan jembatan perkebunan oleh para tukang.

\section{Karakteristik Responden}

\section{Umur Responden}

Umur manusia akan mengalami perubahan dalam hal penambahan usia yang dapat mengakibatkan turunnya produktivitas seseorang dalam bekerja. Umur yang lebih muda tingkat produktivitasnya masih tinggi sedangkan umur yang lebih tua tingkat produktivitasnya semakin rendah, dapat dilihat pada Tabel 1 .

Tabel 1. Jumlah Responden Menurut Umur

\begin{tabular}{llcr}
\hline No & Umur & Jumlah & Persentase $(\%)$ \\
\hline 1 & $<34$ & 2 & 6,67 \\
2 & $35-39$ & 1 & 3,33 \\
3 & $40-44$ & 12 & 40,00 \\
4 & $45-49$ & 6 & 20,00 \\
5 & $50-54$ & 5 & 16,67 \\
6 & $>55$ & 4 & 13,33 \\
\hline & Jumlah & 30 & 100,00 \\
\hline
\end{tabular}

Sumber: Diolah dari data Primer, 2020 
Tabel 1 menunjukkan jumlah responden terbanyak 18 orang dengan persentase $60 \%$, pada umur 40-49 tahun. Jumlah responden tersedikit 12 orang, dengan persentase $10 \%$ pada umur 30 39 tahun.

\section{Pekerjaan responden}

Pekerjaan merupakan sesuatu yang dilakukan setiap anggota masyarakat untuk mendapatkan pendapatan yang dapat memenuhi kebutuhan hidupnya. Responden menurut pekerjaan dilihat pada Tabel 2.

Tabel 2. Responden Menurut Pekerjaan

\begin{tabular}{llcr}
\hline No & Pekerjaan & Responden (Orang) & Persentase $(\%)$ \\
\hline 1 & Petani & 21 & 70,00 \\
2 & Swasta & 5 & 16,67 \\
3 & PNS & 4 & 13,33 \\
\hline & Jumlah & 30 & 100,00 \\
\hline
\end{tabular}

Sumber: Diolah dari Data Primer, 2020

Tabel 2 menunjukkan bahwa sebagian besar berjumlah 21 responden dengan persentase $70 \%$ memiliki pekerjaan dibidang pertanian. Sedangkan 5 responden dengan persentase $16,67 \%$, memiliki pekerjaan sebagai Swasta dan 4 responden dengan persentase $13,33 \%$ memiliki pekerjaan sebagai guru.

\section{Pendidikan responden}

Pendidikan merupakan faktor terpenting dalam perekonomian dan pembangunan demi pencapaian kesejahteraan masyarakat. Pendidikan adalah salah satu kebutuhan pokok dari setiap masyarakat yang berhubungan dengan kualitas sumber daya manusia (SDM) karena semakin tinggi kualitas sumber daya manusia maka pembangunan akan mengalami peningkatan kemajuan yang lebih tinggi. Responden menurut pendidikan dapat dilihat pada Tabel 3 .

Tabel 3. Tingkat pendidikan responden

\begin{tabular}{lccr}
\hline No & Pendidikan & Responden & Persentase (\%) \\
\hline 1 & SMP & 6 & 20,00 \\
2 & SMA & 18 & 60,00 \\
3 & S1 & 6 & 20,00 \\
\hline & Jumlah & 30 & 100,00 \\
\hline
\end{tabular}

Sumber: Diolah dari Data Primer, 2020

Tabel 3 menunjukkan bahwa tingkat pendidikan responden relatif tinggi karena sebagian besar responden (24 orang atau 80\%) berpendidikan SMA keatas.

\section{Partisipasi Masyarakat dalam Pembangunan Jembatan Perkebunan}

\section{Tahap Perencanaan}

Tahap perencanaan merupakan tahap dimana untuk memulai suatu pembangunan yang dilihat dari rencana kegiatan, rencana anggaran sampai rencana penetapan jangka waktu pembangunan jembatan perkebunan. Partisipasi masyarakat pada tahap perencanaan yaitu terbagi dalam bentuk: ide, tenaga, keterampilan, peralatan, dan uang. Skor gabungan partisipasi masyarakat dalam pembangunan jembatan Desa Kaneyan pada tahap perencanaan dapat dilihat pada Tabel 4.

Tabel 4. Skor Gabungan Partisipasi Masyarakat Dalam Pembangunan Jembatan Perkebunan Desa Kaneyan Kecamatan Tareran pada Tahap Perencanaan

\begin{tabular}{clc}
\hline $\begin{array}{c}\text { Interval Skor } \\
\text { Gabungan Ideal }\end{array}$ & Tingkat Partisipasi & $\begin{array}{c}\text { Skor Gabungan } \\
\text { Hasil Penelitian }\end{array}$ \\
\hline $1-150$ & Kurang Berpartisipasi & \\
$151-450$ & Berpartisipasi & 474 \\
$450-750$ & Sangat Berpartisipasi & \\
\hline Persentase skor gabungan hasil & $=\frac{474}{750} \times 100 \%$ \\
penelitian terhadap skor gabungan & \\
\hline Sumber : Diolah dari data primer, 2020 &
\end{tabular}

Tabel 4 menunjukkan bahwa tingkat partisipasi masyarakat dalam tahap perencanaan pembangunan jembatan perkebunan di Desa Kaneyan pada bentuk partisipasi pikiran, tenaga, keterampilan, barang, dan uang termasuk pada kategori Berpartisipasi dengan jumlah skor gabungan 474 dengan interval 151- 450 gambar 1 dan gambar 2 menunjukkan skala skor sebagai berikut: Interpretasi berdasarkan nilai skor $=$ 474.

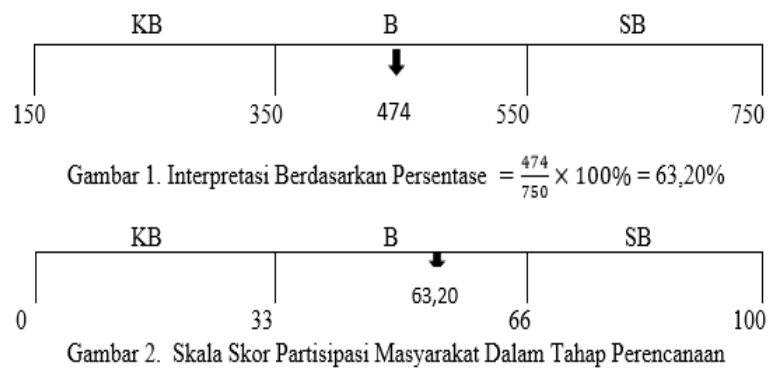

Berdasarkan perhitungan skala likert pada gambar 1 dan gambar 2 menunjukkan bahwa tingkat partisipasi masyarakat dalam tahap perencanaan pembangunan jembatan per-kebunan 
Desa Kaneyan berada pada skala $(63,20 \%)$ termasuk pada kategori berpartisipasi. Pada tahap perencanaan berdasarkan hasil wawancara, partisipasi masyarakat Desa Kaneyan banyak memberikan ide atau pendapat, memberi diri dalam mengikuti rapat serta memberikan sumbangsih berupa konsumsi makanan dan minuman dalam mengikuti rapat pada tahap perencanan pembangunan jembatan perkebunan.

\section{Tahap Pelaksanaan}

Tahap pelaksanaan merupakan tahap dimana kegiatan dengan bentuk fisik dalam bentuk dan tingkat partisipasi masyarakat dengan memberikan waktu dan tenaga dalam program pembangunan jembatan pada tahap pelaksanaan. Dimana dibutuhkan kerjasama dalam bentuk partisipasi pikiran, tenaga, keterampilan, barang dan uang antara lembaga non pemerintah dengan masyarakat pada tahap kegiatan ini, dalam bentuk pembuatan pembangunan jembatan perkebunan dengan tingkat partisipasi responden sangat berpartispasi, berpartisipasi, dan kurang berpartisipasi. Skor gabungan partisipasi masyarakat dalam pembangunan jembatan Desa Kaneyan pada tahap pelaksanaan dapat dilihat pada Tabel 5.

Tabel 5. Skor Gabungan Partisipasi Masyarakat Dalam Pembangunan Jembatan Perkebunan Desa Kaneyan Kecamatan Tareran pada Tahap Pelaksanaan

\begin{tabular}{clc}
\hline $\begin{array}{c}\text { Interval Skor } \\
\text { Gabungan Ideal }\end{array}$ & Tingkat Partisipasi & $\begin{array}{c}\text { Skor Gabungan } \\
\text { Hasil Penelitian }\end{array}$ \\
\hline $1-150$ & Kurang Berpartisipasi & \\
$151-450$ & Berpartisipasi & 436 \\
$450-750$ & Sangat Berpartisipasi & \\
\hline Persentase skor gabungan hasil & $=\frac{436}{750} \times 100 \%$ \\
penelitian terhadap skor gabungan & \\
\hline
\end{tabular}

Sumber : Diolah dari data primer, 2020

Tabel 5 menunjukkan bahwa tingkat partisipasi masyarakat dalam tahap pelaksanaan pembangunan jembatan perkebunan di Desa Kaneyan dalam bentuk partisipasi pikiran, tenaga, keterampilan, barang, dan uang termasuk pada kategori Berpartisipasi dengan jumlah skor gabungan 436 dengan interval 151- 450 dilihat pada gambar 3 dan gambar 4 skala skor sebagai berikut: Interpretasi berdasarkan nilai skor $=436$.

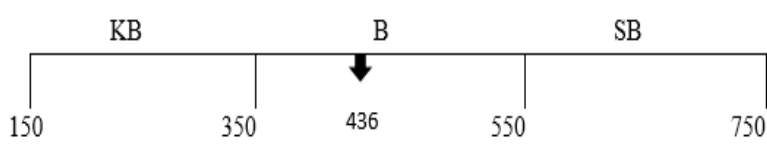

Gambar 3. Interpretasi berdasarkan persentase $==\frac{436}{750} \times 100 \%=58,13 \%$

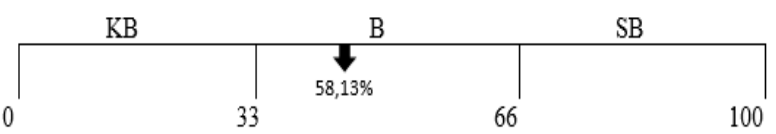

Gambar 4. Skala skor partisipasi masyarakat pada tahap pelaksanaan.

Berdasarkan perhitungan skala likert pada gambar 3 dan gambar 4 menunjukkan bahwa tingkat partisipasi masyarakat dalam tahap pelaksanaan pembangunan jembatan perkebunan Desa Kaneyan berada pada skala $(58,13 \%)$ termasuk pada kategori Berpartisipasi. Pada tahap pelaksanaan berdasarkan hasil wawancara, partisipasi masyarakat Desa Kaneyan berupa kerja bakti untuk pembersihan daerah sungai yang akan dibangun sebuah jembatan. Masyarakat juga memberikan sumbangsih bahan berupa makanan dan minuman, masyarakat Desa Kaneyan juga saling memberikan dorongan berupa motivasi diantaranya memberikan semangat kepada mereka yang terlibat langsung untuk menyelesaikan pembuatan pembangunan jembatan perkebunan, dan juga saling memberikan motivasi kepada masyarakat dalam perbedaan pendapat pada proses pembangunan.

\section{Tahap Pemeliharaan}

Tahap pemeliharaan ini adalah tahap dimana masyarakat mengambil bagian untuk berpartisipasi dalam melakukan pemeliharaan dengan memastikan apakah program yang telah direncanakan telah berjalan dengan baik sesuai yang diharapkan. Skor gabungan partisipasi masyarakat dalam pembangunan jembatan Desa Kaneyan pada tahap pemeliharaan dapat dilihat pada Tabel 6.

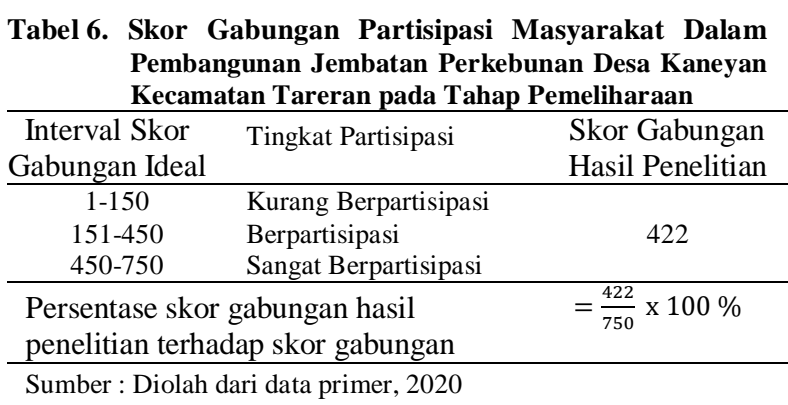


Tabel 6 menunjukkan bahwa tingkat partisipasi masyarakat dalam tahap pemeliharaan pembangunan jembatan perkebunan di Desa Kaneyan dalam bentuk partisipasi pikiran, tenaga, keterampilan, barang, dan uang termasuk pada kategori Berpartisipasi dengan jumlah skor gabungan 422 dengan interval 151- 450 di lihat dari gambar skala skor sebagai berikut: Interpretasi berdasarkan nilai skor $=422$. Dapat dilihat pada gambar 5 dan gambar 6.

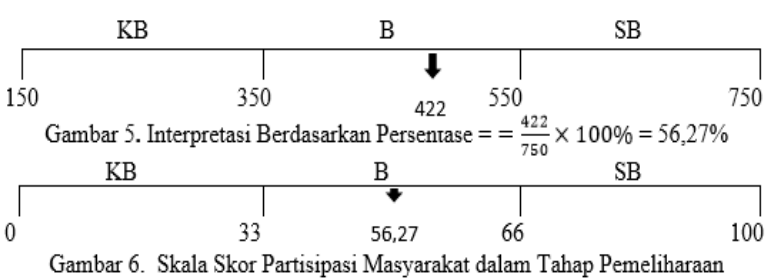

Berdasarkan skala likert pada gambar 5 dan gambar 6 menunjukkan bahwa tingkat partisipasi masyarakat dalam tahap pemeliharaan pembangunan jembatan perkebunan Desa Kaneyan berada pada skala $(56,27 \%)$ termasuk pada kategori berpartisipasi. Pada tahap pemeliharaan berdasarkan hasil wawancara, partisipasi masyarakat Desa Kaneyan memberikan tenaga berupa mengikuti kerja bakti yang dilaksanakan dalam waktu 3 bulan setelah jembatan ini selesai di bangun, untuk menjaga agar tidak terjadi kerusakan diwaktu yang singkat karena pembangunan jembatan ini merupakan akses penghubung dari wilayah desa ke lokasi perkebunan.

Tabel 7. Skor Gabungan Partisipasi Masyarakat Dalan Pembangunan Jembatan Perkebunan

\begin{tabular}{clc}
\hline $\begin{array}{c}\text { Interval Skor } \\
\text { Gabungan Ideal }\end{array}$ & Tingkat Partisipasi & $\begin{array}{c}\text { Skor Gabungan } \\
\text { Hasil Penelitian }\end{array}$ \\
\hline $1-150$ & Kurang Berpartisipasi & \\
$151-450$ & Berpartisipasi & 1294 \\
$450-750$ & Sangat Berpartisipasi & \\
\hline Persentase skor gabungan hasil & $=\frac{1294}{750} \times 100 \%$ \\
penelitian terhadap skor gabungan & \\
\hline Sumber : Diolah dari data primer, 2020 &
\end{tabular}

Tabel 7 menunjukkan bahwa tingkat partisipasi masyarakat dalam pembangunan jembatan perkebunan berdasarkan skor gabungannya termasuk dalam kategori berpartisipasi. Interpretasi berdasarkan nilai skor $=1294$ dapat dilihat pada gambar 7 dan gambar 8 .

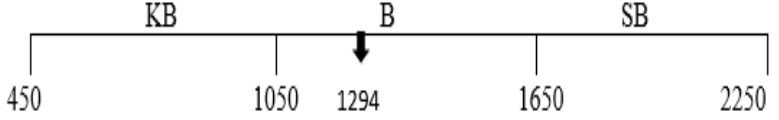

Gambar 7. Interpretasi Berdasarkan Persentase $==\frac{1294}{2250} \times 100 \%=57,51 \%$

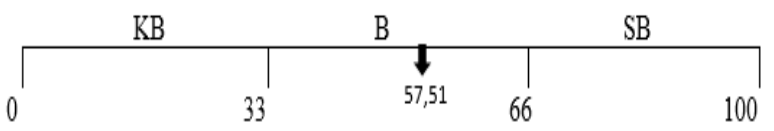

Gambar 8. Skala Skor Partisipasi Masyarakat dalam Tahap Perencanaan, Tahap Pelaksanaan, dan Tahap Pemeliharaan

Berdasarkan skala likert tersebut maka dapat dikatakan bahwa tingkat partisipasi masyarakat dalam pembangunan jembatan perkebunan Desa Kaneyan pada tahap perencanaan, pelaksanaan, dan pemeliharaan berada pada skala $(57,51 \%)$ termasuk pada kategori Berpartisipasi. Dimana keseluruhan masyarakat yang ada masih berpartisipasi dalam menunjang program pemerintah dalam hal ini memberikan pikiran atau ide, memberikan tenaga, kreativitas dan meminjamkan peralatan serta membawa konsumsi berupa makanan dan minuman pada tahap perencanaan, tahap pelaksanaan dan tahap pemeliharaan dalam pembuatan pembangunan jembatan perkebunan.

Berdasarkan hasil analisa masing-masing indikator maka hasil rekapitulasi dapat dilihat pada Tabel 8.

Tabel 8. Rekapitulasi Partisipasi Masyarakat dalam Pembangunan Jembatan Perkebunan

\begin{tabular}{lllrl}
\hline No Tahap Partisipasi & Skor & Persentase $(\%)$ & Keterangan \\
\hline 1 & Perencanaan & 474 & 63,20 & Berpartisipasi \\
2 & Pelaksanaan & 436 & 58,13 & Berpartisipasi \\
3 & Pemeliharaan & 422 & 56,27 & Berpartisipasi \\
\hline \multicolumn{2}{c}{ Jumlah } & 1294 & 57,51 & Berpartisipasi \\
\hline
\end{tabular}

Sumber: Diolah Dari Data Primer, 2020

Tabel 8 menunjukkan bahwa partisipasi dalam pembangunan jembatan perkebunan pada tahap perencanaan skor 474 dengan nilai persentase $(63,20 \%)$. Sedangkan tahap pelaksanaan skor 436 dengan nilai persentase $(58,13 \%)$. Dan tahap pemeliharaan 422 dengan nilai persentase $(56,27 \%)$. Hal ini menunjukkan partisipasi masyarakat dalam pembangunan jembatan perkebunan pada tahap perencanaan, pelaksanaan, sampai pemeliharaan termasuk pada kategori berpartisipasi. 
Tabel 9. Rekapitulasi Persentase Bentuk Partisipasi Masyarakat dalam Pembangunan Jembatan Perkebunan pada Tahap Perencanaan, Pelaksanaan, dan Pemeliharaan

\begin{tabular}{|c|c|c|c|c|c|}
\hline \multirow[t]{2}{*}{ No } & \multirow[t]{2}{*}{$\begin{array}{c}\text { Tahap } \\
\text { partisipasi }\end{array}$} & \multirow[t]{2}{*}{$\begin{array}{c}\text { Bentuk } \\
\text { Partisipasi }\end{array}$} & \multicolumn{3}{|c|}{$\begin{array}{c}\text { Total persentase }(\%) \\
\text { Kriteria }\end{array}$} \\
\hline & & & $\begin{array}{c}\text { Sangat } \\
\text { Berpartisipasi }\end{array}$ & Berpartisipasi & $\begin{array}{c}\text { Kurang } \\
\text { Berpartisipasi }\end{array}$ \\
\hline \multirow[t]{5}{*}{1} & Perencanaan & Pikiran (Ide) & 84,56 & 15,44 & 0,00 \\
\hline & & Tenaga & 84,56 & 15,44 & 0,00 \\
\hline & & Keterampilan & 46,05 & 35,03 & 18,42 \\
\hline & & Perlengkapan & 0,00 & 72,41 & 27,59 \\
\hline & & Uang (Dana) & 22,06 & 57,35 & 20,59 \\
\hline \multirow[t]{5}{*}{2} & Pelaksanaan & Pikiran (Ide) & 84,56 & 15,44 & 0,00 \\
\hline & & Tenaga & 83,33 & 5,88 & 10,78 \\
\hline & & Keterampilan & 23,44 & 51,56 & 25,00 \\
\hline & & Perlengkapan & 37,76 & 39,71 & 23,53 \\
\hline & & Uang (Dana) & 37,88 & 36,36 & 25,76 \\
\hline \multirow[t]{5}{*}{3} & Pemeliharaan & Pikiran (Ide) & 88,24 & 0,00 & 11,76 \\
\hline & & Tenaga & 88,24 & 0,00 & 11,76 \\
\hline & & Keterampilan & 59,52 & 25,00 & 15,48 \\
\hline & & Perlengkapan & 15,63 & 60,94 & 23,44 \\
\hline & & Uang (Dana) & 25,86 & 41,38 & 32,76 \\
\hline
\end{tabular}

Sumber: Diolah dari data primer, 2020

Tabel 9 menunjukkan bahwa pada tahap perencanaan, tahap pelaksanaan dan tahap pemeliharaan partisipasi masyarakat yaitu berpartisipasi dalam menunjang program pemerintah dalam hal ini memberikan pikiran atau ide, memberikan tenaga, kreativitas dan meminjamkan peralatan serta membawa konsumsi berupa makanan dan minuman pada tahap perencanaan, tahap pelaksanaan dan tahap pemeliharaan dalam pembuatan pembangunan jembatan perkebunan.

\section{KESIMPULAN DAN SARAN}

\section{Kesimpulan}

Berdasarkan hasil penelitian yang di lakukan di Desa Kaneyan Kecamatan Tareran Kabupaten Minahasa Selatan menunjukkan bahwa tingkat partisipasi masyarakat Desa Kaneyan dalam program pembangunan jembatan perkebunan pada tahap perencanaan, tahap pelaksanaan, dan tahap pemeliharaan berada pada persentase $57,51 \%$ termasuk pada kategori Berpartisipasi, dan dalam bentuk partisipasi (ide), tenaga, keterampilan, barang (perlengkapan), dan uang (dana) termasuk pada kategori Berpartisipasi.

\section{Saran}

Dengan adanya program pemerintah yaitu pembangunan jembatan perkebunan di Desa Kaneyan Kecamatan Tareran, tingkat partisipasi masyarakat pada penelitian ini termasuk pada kategori Berpartisipasi. Disarankan untuk program pembangunan pemerintah Desa selanjutnya baik yang di anggarkan lewat Dana Desa maupun dana lainnya tingkat partisipasi masyarakat Desa Kaneyan dapat meningkat sampai pada kategori Sangat Berpartisipasi. Peningkatan partisipasi masyarakat pada tahap perencanaan dan tahap pelaksanaan diharapkan dapat meningkatkan partisipasi pada tahap pemeliharaan sehingga dapat memperpanjang umur jembatan.

\section{DAFTAR PUSTAKA}

Adisasmita, R. 2006. Pembangunan Pedesaan dan Perkotaan. Yogyakarta: Graha Ilmu.

Anonim, 2019. Gambaran umum Desa Kneyan, Kecamatan Tareran, Kabupaten Minahasa Selatan https://id.m.wikipedia.org/wiki/

Kaneyan,_Tareran,_Minahasa,_Selatan diakses pada tanggal 3 Desember 2019. Pukul 21:40 WITA.

Effendi A. 2014. Peran Kepala Desa dalam Meningkatkan Pembangunan Fisi di Desa Salingkau Kecamatan Kaliorang Kabupaten Kutai Timur. Ejournal Ilmu Pemerintahan, 2014, 2 (2): 25802593 ISSN 23383651.ejournal.ip.fisip.unmul.ac .id.

Hamijoyo, S. 2007. Pembangunan Masyarakat berwawasan Partisipasi, Yogyakarta: UGM Press.

Juliantara, D. 2004. Pembaruan Kabupaten Arah Realisasi Otonomi Daerah. Pustaka Jakarta: Jaya Mandiri.

Kuncoro, M. 2010. Dasar-dasar Ekonomika Pembangunan. Yogyakarta: UPP STIM YKPN.

Mikkelsen, B. 2011. Metode Penelitian Partisipatoris Dan Upaya Pemberdayaan: Panduan Bagi Praktisi Lapangan. Jakarta: Yayasan Pustaka Obor Indonesia.

Mustanir, A. 2016. Implementasi Kebijakan Dana Desa Dan Partisipasi Masyarakat Dalam Pembangunan Di Desa Teteaji Kecamatan Tellu Limpoe Kabupaten Sidenreng Rappang. JPP (Jurnal Politik Profetik), 4(2): 225-38.

Mustanir, A., \& Jusman, J. 2016. Implementasi Kebijakan dan Efektivitas Pengelolaan terhadap Penerimaan Retribusi di Pasar Lancirang Kecamatan Pitu Riawa Kabupaten Sidenreng Rappang. AKMEN Jurnal Ilmiah, 13(3): 542-558.

Rorong, F., Rares, J. J. dan Ruru, J. M. 2017. Partisipasi Masyarakat dalam Pembangunan Infrastruktur di Desa Tolombukan Satu Kecamatan Pasan Kabupaten Minahasa Tenggara. Jurnal Administrasi Publik, 3(046).

Slamet, Y. 1993. Pembangunan Masyarakat Berwawasan Partisipasi. Sebelas Maret University Press.

Wresniwiro, 2012. Membangun Republik Desa. Jakarta: Visi Media. 